\title{
Padepokan, Pesantren, dan Hari Santri
}

Vitradesie Neokent

Ibu dua putri, pemerhati pendidikan

Sebagai ibu rumah tangga, saya mengalami "gegana intelektual" ketika menerima pertanyaan apa perbedaan padepokan dan pesantren dari putri saya yang duduk di bangku SD. Gelisah saya terjadi karena pemberitaan media massa dan TV yang masif seputar dugaan kejahatan yang terjadi di padepokan. Galau karena saya tak punya cukup jawaban untuk memberi dasar logika kejadian tersebut. Dan menjadi merana karena memikirkan, kapan negara ini akan menjadi negara maju manakala kita masih terus berkutat dengan hal-hal semacam ini dari waktu ke waktu. Karenanya, sebagai sumber pengetahuan primer dalam keluarga, saya menulis artikel ini dengan merujuk pada sependek data, informasi, pengetahuan, dan kebijaksanaan yang saya miliki. Saya juga berpikir bahwa masyarakat - terutama alim ulama dan cendikiawan - memiliki kewajiban untuk menjelaskan perbedaan padepokan dan pesantren, utamanya karena kita akan menyongsong Hari Santri Nasional pada tanggal 22 Oktober nanti.

\section{Padepokan}

Berdasar Kamus Besar Bahasa Indonesia (KBBI), kata padepokan tidak memiliki arti yang dijelaskan secara spesifik, namun disepadankan dengan kata tempat, sanggar. Ketiadaan makna padepokan pada kamus yang menjadi rujukan akademik, menunjukkan bukti bahwa kata padepokan merupakan istilah yang dianggap sebagai taken for granted atau sebagai istilah yang telah dipahami bersama tanpa perlu diberikan batasan pengertian.

Sedangkan sumber berita daring yang berasal dari satu blog pribadi menyatakan bahwa kata padepokan berasal dari Bahasa Jawa yang bermakna asrama dan sekolah yang menjadi satu untuk kegiatan belajar dan mengajar berbagai macam ilmu. Padepokan lebih dikenal sebagai tempat belajar dan penggemblengan juga tempat tinggal para pendekar dalam dunia persilatan. Pada mulanya, kata padepokan adalah tempat tinggal para pujangga dalam masyarakat Jawa. Namun seiring perjalanan waktu, karena pujangga juga menguasai ilmu kanuragan dan kebatinan maka sebagian besar masyarakat Jawa beranggapan padepokan merupakan tempat penggemblengan para pendekar. Adapun pengertian dari sumber daring lain menyebutkan bahwa padepokan adalah tempat menuntut ilmu. 
Saya mengalami cukup kesulitan untuk menemukan referensi akademik terkait padepokan, sehingga tulisan ini terbatas pada informasi yang tersedia pada website pemerintah dan sumber berita daring. Padepokan bernaung di bawah yayasan yang ijinnya dikeluarkan oleh Kemenkumham. Yayasan memiliki Anggaran Dasar dan Anggaran Rumah Tangga yang menjadi legalitas aktivitasnya. Dalam hal apa saja mereka beraktivitas? Beberapa padepokan menawarkan ilmu agama, ilmu pengetahuan (seperti: penguasaan bahasa asing), ilmu kesaktian (seperti: kekebalan tubuh), kesehatan dan kesembuhan, kekayaan materi, perjodohan, maupun peningkatan karir. Sistem pembayaran dikenal sebagai mahar, yang dapat berupa uang tunai maupun benda-benda berharga, seperti: logam mulia, patung, lukisan, keris, maupun aset berupa tanah/rumah.

Padepokan juga tidak berafiliasi dengan agama tertentu. Padepokan menerima pengikut yang berasal dari lintas agama, dan tidak mensyaratkan mereka untuk berpindah keyakinan. Agama Islam sering diafiliasikan dengan pesantren, setidaknya karena dua hal. Pertama, padepokan terkadang menggunakan ritual agama Islam, seperti salat dan membaca Quran sebagai sarana. Kedua, secara mayoritas, padepokan dipimpin oleh personil yang beragama Islam.

Pemimpin padepokan memiliki beberapa penyebutan, seperti: Kyai, Kanjeng, Tetua, Guru, atau Suhu. Sedang anggota padepokan disebut sebagai pengikut. Padepokan tidak memiliki ijin sebagai penyelenggara pendidikan formal maupun informal. Hal ini dibuktikan dengan tidak adanya ijin yang dikeluarkan oleh Kemendikbud (sebagai penyelenggaran pendidikan dasar hingga menengah) dan Kemenristekdikti (sebagai penyelenggaran pendidikan tinggi) maupun Kemenag sebagai penyelenggaran pendidikan Islam. Yang perlu memperoleh perhatian penting dari masyarakat adalah keberadaan padepokan yang memproklamirkan diri juga sebagai padepokan pesantren. Ragam pendidikan padepokan pesantren tidak dikenal dalam sistem pendidikan di Indonesia.

Fenomena dugaan penipuan oleh pemimpin padepokan dapat dijelaskan menggunakan pendekatan permintaan dan penawaran. Dari sisi permintaan, terdapat kultur dalam masyarakat yang menginginkan suatu hal dapat terjadi secara instan atau lebih dikenal sebagai ujug-ujug ana. Untuk mendapatkan keinginannya (dan bukan kebutuhannya), manusia selalu akan dihadapkan pada pilihan rasional atau irasional. Faktor pendidikan, tidak mendukung dugaan bahwa mereka yang terpelajar akan menjadi lebih rasional dibanding yang kurang terpelajar. 
Motivasi irasional lebih dapat dijelaskan pada kebiasaaan sehari-hari atau ketidakpedulian terhadap hal irasional yang kemudian justru menjelma ke dalam nuansa bawah sadar manusia dan mewujud menjadi perilaku. Kognitif manusia merekam segala hal secara dikehendaki maupun tidak. Sehingga, kurangnya filter manusia terhadap hal-hal buruk dan di luar logika secara tidak sadar menjadi memori yang tersimpan lekat dan suatu saat dapat dibangkitkan oleh adanya stimulus.

Hal lain dari sisi permintaan sebenarnya sangat berkorelasi dengan terjadinya perubahan lingkungan dan kerusakannya. Penyakit degeneratif yang muncul akibat menurunnya fungsi organ tubuh merupakan bukti atas ketidakseimbangan ekosistem. Penyakit menimbulkan keresahan yang mengakibatkan dampak berganda bagi keluarga dan masyarakat secara luas. Mereka yang sakit (termasuk keluarga) terkadang kehilangan rasionalitas dan keyakinan akan keimanan. Diperburuk dengan layanan kesehatan mendasar yang belum memadai dan berbiaya tinggi.

Permintaan masyarakat akan sesuatu yang instan, tentu saja menimbulkan penawaran dari sebagian masyarakat lain yang memiliki kapabilitas untuk memenuhinya. Dari perspektif ini, maka kita menyaksikan bersama munculnya sumur-sumur, mata air, bebatuan, dan benda-benda lain yang akan dianggap sebagai penyembuh. Kita juga akan menyaksikan munculkan tokohtokoh yang menganggap dirinya memiliki "kelebihan" karena dapat menyembuhkan segala penyakit, menjamin keselamatan, dan menjanjikan kekayaan.

Namun demikian, keberadaan padepokan tidak seharusnya dipandang negatif oleh masyarakat dan pemerintah. Padepokan adalah bentuk keragaman kearifan lokal dalam tatanan budaya di Indonesia. Padepokan harus diapresiasi, diidentifikasi, didata, dan dikelola segenap potensi yang dimilikinya, meliputi: sarana pendidikan informal, penggerak perekonomian regional, pelestari budaya dan kearifan lokal, serta penjaga nilai-nilai sejarah bangsa. Jika bukan masyarakat sekitar dan pemerintah yang bergerak, maka keberadaan padepokan tidak akan menjadi entitas strategis yang memiliki potensi pemberdayaan umat.

\section{Pesantren}

Menurut Direktorat Pendidikan Islam Kemenag, pesantren adalah lembaga penyelenggara Pendidikan Keagamaan Islam berbasis masyarakat yang menyelenggarakan pendidikan diniyah atau secara terpadu dengan jenis pendidikan lainnya dengan ciri-ciri sebagai berikut: 1) dipimpin oleh kyai; 2) memiliki murid yang disebut santri; 3) berasrama; 4) pengajian 
kitab kuning; 5) dilengkapi dengan masjid atau mushala. Pesanteren merupakan Sub-Sistem Pendidikan Nasional yang berakar pada sistem pendidikan agama dan keagamaan Islam.

Menurut Asroni (2014), keberadaan pesantren telah banyak memberikan kontribusi dalam membangun peradaban Islam di Asia Tenggara. Dalam konteks Indonesia, pesantren dapat disebut sebagai institusi pendidikan Islam asli (indigenous) dan tertua di Indonesia. Bahkan, kehadirannya telah ada jauh sebelum Indonesia merdeka. Laporan Pemerintah Belanda tahun 1831 tentang lembaga-lembaga penduduk "asli" Jawa menyebutkan bahwa jumlah lembaga-lembaga Islam seperti pesantren mencapai 1.853 buah. Di samping menunjukkan akar kesejarahan yang panjang, data kuantitatif tersebut menjadi bukti bahwa pesantren memiliki kontribusi yang besar dalam mencerdaskan kehidupan bangsa. Dalam sejarahnya, pesantren pernah menjadi satu-satunya institusi pendidikan milik masyarakat pribumi yang telah memberi kontribusi sangat besar dalam membentuk masyarakat melek huruf (literacy) dan melek budaya (cultural literacy). Di samping itu, pesantren juga dikenal sebagai basis perlawanan terhadap pemerintah kolonial. Banyak ulama pesantren dan santri yang berjihad melawan pemerintah kolonial. Gerakan perlawanan tersebut banyak dimotori dari dan oleh para penghuni pesantren. Beberapa contoh di antaranya adalah pemberontakan petani di Cilegon-Banten tahun1888, Jihad Aceh tahun 1873, atau gerakan yang dimotori oleh H. Ahmad Ripangi Kalisalak tahun 17861875 .

Sampai di sini, saya kekurangan ide untuk mendeskripsikan pesantren, ust..

\section{Hari Santri}

Hari Santri ditetapkan jatuh pada tanggal 22 Oktober oleh Presiden Jokowi melalui Keppres No. 22 Tahun 2015 yang ditandatangani tanggal 15 Oktober 2015. Berdasar keppres tersebut, pertimbangan ditetapkannya Hari Santri adalah: a) peran besar ulama dan santri di pondok pesantren dalam perjuangan merebut kemerdekaan Republik Indonesia dan mempertahankan Negara Kesatuan Republik Indonesia serta mengisi kemerdekaan; b) untuk mengenang, meneladani, dan melanjutkan peran ulama dan santri dalam membela dan mempertahankan Negara Kesatuan Republik Indonesia serta berkontribusi dalam pembangunan bangsa; c) tanggal 22 Oktober tersebut diperingati merujuk pada ditetapkannya seruan resolusi jihad pada tanggal 22 Oktober 1945 oleh para santri dan ulama pondok pesantren dari berbagai 
penjuru lndonesia yang mewajibkan setiap muslim untuk membela tanah air dan mempertahankan kemerdekaan Negara Kesatuan Republik lndonesia dari serangan penjajah.

Berdasar data dari Renstra Direktorat Pendidikan Islam tahun 2015-2019, hingga tahun 2014, terdapat 27.290 pesantren di Indonesia yang menyelenggaran pendidikan Islam secara salafiyah (kitab kuning), khalafiyah, maupun kombinasi keduanya. Jumlah peserta didik sebanyak 3,65 juta dengan 280 ribu pengajar. Sebagai bagian dari upaya perluasan dan pemerataan akses Pendidikan Islam dan untuk memenuhi kebutuhan pendidikan bagi seluruh kalangan masyarakat, Kemenag menyelenggarakan kegiatan paket dan non formal pada pondok pesantren yang terdiri dari: penyelenggaraan Paket A dan B, penyelenggaraan Paket C, penyelenggaraan PPS Program Wajar Dikdas, dan pendidikan lifeskill dan short course pendidikan non formal.

Peringatan Hari santri yang kedua di tahun ini akan dilaksanakan diberbagai daerah dengan agenda yang menarik dan meneguhkan identitas keislaman, Namun, saya cukup tertarik untuk mengetahui bagaimana pendapat dunia akademik internasional akan keberadaan pesantren di Indoensia (yang diterjemahkan sebagai islamic boarding school). Berdasar artikel Smith (2014) yang berjudul "Sexual Desire, Piety, and Law in a Javanese Pesantren: Interpreting Varieties of Secret Divorce and Polygamy" yang terbit di jurnal Anthropological Forum, terdapat beberapa temuan menarik yang menggambarkan keberadaan wanita dalam lingkungan pesantren yang kurang memperoleh atensi dari para peneliti antropologi. Dengan menggunakan pandangan feminis, Smith (2014) menantang wacana poligami dan nikah batin bagi wanita di lingkungan pesantren dan menyerukan bahwa wanita memiliki hak yang sama di mata hukum dan agama untuk menentukan hak-haknya dalam pernikahan.

Artikel menarik lain ditulis Tikves dkk (2012). Mereka menyusun profil idiologi dan pola aktivitas dari 23 website milik organisasi Islam di Indonesia. Keduapuluh tiga website tersebut kemudian dianalisis dan menghasilkan 37.000 artikel yang diterbitkan selama tahun 2001-2011. Analisis juga diperkuat dengan sistem kepakaran yang dirumuskan dalam bentuk algorima, sehingga menghasilkan beberapa skenario eksperimen. Temuan penelitian menunjukkan posisi organisasi Islam di Indonesia berdasar empat kuadran yang menunjukkan kombinasi antara organisasi yang menginginkan atau tidak menginginkan perubahan, dan organisasi yang menggunakan atau tidak menggunakan kekerasan. Kuadran paling ekstrim 
adalah kuadran dimana terdapat organisasi yang menginginkan perubahan dengan cara kekerasan.

Untuk penutup dan memberi pesan, saya juga sedang mencari ide. 